\title{
Assessment of Genetic Diversity in some Egyptian Cotton Varieties Based on Molecular and Technological Characteristics
}

\author{
Walaa G. Mohamed ${ }^{1}$, Ibrahim A.E. Ibrahim ${ }^{2}$ and Nader R. Abdelsalam ${ }^{1}$
}

\begin{abstract}
Cotton is an economic plant of world importance. It's the world's leading textile fiber crop. The lack of genetic diversity is implicated in the successful breeding program depends on the slowing of progress in developing new cotton cultivars complete knowledge and understanding of the genetic with improved yield and quality potential, as well as diversity within and among genetic resources of the stress resistance. The present study was carried out at the Agricultural Botany Department and Department of Plant production Faculty of Agriculture, Saba Basha, Alexandria University, Egypt. Five commercial varieties representing the two categories of Egyptian cotton were used, namely: Giza 92 and Giza 88 as extra-long staple length and Giza 86, Giza 95 and Giza 90 as long staple length. These studies were conducted during 2015 up to 2018. Fiber properties of the five cotton varieties under study were determined by the High-Volume Instrument (H.V.I.). Ten RAPD primer, were initially screened to determine the suitability of each primer for the study. Isozyme data proved $100 \%$ genetic similarity between the extra-long staple cotton, in the other hand $100 \%$ between the long staple cotton varieties, although, the cluster was divided by $62 \%$. The results indicated that in all studied cotton varieties, $224(71 \%)$ of the 312 fragments were polymorphic and $88(29 \%)$ were monomorphic. From these data, we can provide that there are high genetic variations between the two-cotton type in Egypt and these found could be useful in breeding program in the future. Cotton productivity and the future of cotton breeding efforts tightly depend on the level of the genetic diversity of cotton gene pools and its effective exploitation in cotton breeding programs. Elucidating the details of genetic diversity is also very important to determine timeframe of cotton agronomy, develop a strategy for genetic gains in breeding, and conserve existing gene pools of cotton.
\end{abstract}

Key words: Cotton, Technology, Biochemical, Molecular markers.

\section{INTRODUCTION}

The genus Gossypium of the family Malvaceae contains more than 45 diploid species and 5 allotetraploid species (Ulloa et al., 2006). These species are grouped into nine genomic types $(2 n=26)$ with designations: AD, A, B, C, D, E, F, G, and K (Percival et al., 1999). The species are largely spread throughout the diverse geographic regions of the world. Cotton is the world's leading textile fiber crop and it is also a source of secondary products such as oil, live-stock feed and cellulose (Anderson, 1999). Cotton is the unique, most important natural fiber crop in the world that brings significant economic income, with an annual average ranging from $\$ 27: 29$ billion worldwide from lint fiber production (Campbell et al., 2010). In Egypt, cotton is one of the most important genotypes. Knowledge of genetic diversity, technological and economic parameters as it plays a vital role in our relationships among breeding materials. The total cultivated area began to decline, which mean analysis is a quantitative genetic method be requires working to increase the production of unit able to estimate additive, dominance and epistatic area to compensate for the shortfall in the effects (Mather and Jinks, 1982). Genetic analysis using generation means cultivated area. The breeders should develop some new generations in cotton breeding to estimate the set of varieties with higher production, the true type of gene action controlling of quantitative traits knowledge of the gene action for various cotton (Dawwam et al., 2009). The lack of genetic diversity is implicated in the successful breeding program depends on the slowing of progress in developing new cotton cultivars complete knowledge and understanding of the genetic with improved yield and quality potential, as well as diversity within and among genetic resources of the stress resistance. To broad the cotton genetic available germplasm and enable plant breeders to base, this may be accomplished by collection of available choose parental sources that will generate diverse germplasm or developing inter and intra-specific hybrids. The amplitude of genetic diversity of cotton (Gossypium spp), including all its morphological, physiological and agronomic properties, is exclusively wide (Mauer, 1954). There is a great deal of genetic diversity in the Gossypium genus with characteristics such as plant architecture, stem pubescence and color, leaf plate shape, flower color, pollen color, boll shape, fiber quality, yield potential, early maturity, photoperiod dependency, and resistance to multi-adversity environmental stresses that are important for the applied breeding of cotton. Above mentioned genetic diversity, preserved in germplasm collections worldwide, are the golden resources to genetically improve the cotton cultivars. There are numerous examples on the utilization

\footnotetext{
${ }^{1}$ Agricultural Botany Dept., Faculty of Agriculture (Saba Basha), Alex. Uni., Egypt

Plant Production Dept., Faculty of Agriculture (Saba Basha), Alex. Uni., Egypt

Received March 03, 2018, Accepted March 28, 2018
} 
of such genetic variations in solving many fundamental problems in cotton breeding and production (Abdurakhmonov, 2007). Assessment of genetic markers and diversity form an integral part of any successful breeding program. Morphological features are indications of the genotype but are represented by only a few loci because there are not a large enough number of characters available. Moreover, they can also be affected by environmental factors and growth practices. To overcome the limitations associated with morphological markers, various biochemical and molecular marker techniques have come up in recent years. Biochemical markers such as isozymes have been used to study the genetic distances and estimate the level of genetic variability of cotton varieties and accessions (Wendel and Percy, 1990; Abdel-Tawab et al., 1990; Melchinger et al., 1991; Farooq et al., 1999). The RAPD markers have already been used in cotton for the assessment of genetic variability, diversity and fingerprinting cotton genotypes (Pillay and Myers, 1999; Jing et al., 2000; Hussein et al. 2002; Muhammad et al., 2009; Zahid et al., 2009) as well as for the detection of variation between closely related cultivars (El-Defrawy et al., 2004; Masoud et al., 2007). The main objectives of the present research are to study some technological parameters between some Egyptian cotton varieties, assessment the morphological variations, determine the genetic differences, calculate the genetic polymorphism with/within some cotton varieties based on molecular markers.

\section{MATERIALS AND METHODS}

Five commercial varieties representing the two categories of Egyptian cotton were used, namely: Giza 92 and Giza 88 as extra-long staple length (over $1 \frac{3}{8^{-}}$ inch fiber length) and Giza 86, Giza 95 and Giza 90 as long staple length $\left(1 \frac{1}{4}-1 \frac{3}{8}\right.$ inch) fiber length. Cotton seeds were planted on four replicates each in pots.

Ten plants and six replicates were selected from the above-mentioned varieties for all experiments. Five morphlogical characters were musered such as follws: plant height $(\mathrm{cm})$, root length $(\mathrm{cm})$, leaves number and bolls number/plant.

Fiber properties of the five cotton varieties were determined by H.V.I. at the laboratory of the Cotton Arbitration and Testing General Organization (CATGO), Alexandria, Egypt. Samples were preconditioned for 48 hours at least under the standard conditions of $65 \% \pm 2 \%$ relative humidity and $20 \pm 1$ ? C temperature before testing. The technological fiber parameters were determined as following: Micronaire reading, Fiber maturity (\%), Upper half mean length, (UHML) (mm), Fiber uniformity (\%), Short fiber content (\%), Fiber strength (g/tex), Fiber elongation $(\%)$, Reflectance degree (Rd \%) and Degree of yellowness $\left({ }^{+} b\right)$. The technological parameters mean were compared using the least significant differences (L.S.D.) test at 5\% level of probability by using the RCBD model as obtained by CoStat computer software package (CoStat, Ver. 6.4, 2005).

Five leaves from cotton seedlings were grounded separately, using a cooled mortar with a pestle, and adding $0.23 \mathrm{M}$ Tris-acetate, $\mathrm{pH}$ 5.0. Homogenate was extracted by the solution containing Tris $(27.7 \mathrm{~g})$ and citric acid $(11.0 \mathrm{~g})$ in $1 \mathrm{~L}$ volume adjusted with distilled water. Electrophoresis was carried out by the prescriptions recommending 1\% agar-starch-olyvinylpyrrolidone gel and Tris-orate or Tris-acetate separation buffers. Electrophoresis was conducted at $270 \mathrm{v}, 4$ ?C for $100 \mathrm{~min} .100 \mathrm{ml}$ of $0.01 \mathrm{M}$ acetate buffer; $\mathrm{pH} 5.0$, containing $0.1 \%$ benzidine and $0.5 \%$ hydrogen peroxide $\left(\mathrm{H}_{2} \mathrm{O}_{2}\right)$ were layered over the gel immediately before staining. Based on the matrix of genetic similarity values (peroxidase isozymes data) and the dendrogram was generated from the genetic distance matrix according to UPGMA clustering method using NTSYSpc program (Rohlf, 2000) was developed to identify genetic variation patterns among the four cultivars and lines of wheat under study.

Ten RAPD primers (10-mer primers), were initially screened using five cotton cultivars to determine the suitability of each primer for the study. Primers were selected for further analysis based on their ability to detect distinct, clearly resolved and polymorphic amplified products within the samples. To ensure reproducibility, the primers generating no, weak, or complex patterns were discarded (Williams et al. 1990). DNA extracted from $50 \mathrm{mg}$ samples of leaves of cotton material using either the DNeasy ${ }^{\circledR}$ Plant System according to Murray and Thompson, (1980). RAPD analyze was carried out using 10 oligonucleotide primers that were selected from the Operon Kit (Operon Technologies Inc., Alabameda, CA). The polymerase chain reaction mixture $(25 \mu \mathrm{l})$ consisted of $0.8 \mathrm{U}$ of $\mathrm{Taq}$ DNA polymerase; $25 \mathrm{pmol}$ dNTPs; $25 \mathrm{pmol}$ of primer and 50ng of genomic DNA. PCR amplification was performed in a Biometra $T 1$ gradient thermal cycler for 40 cycles after initial denaturation for $3 \mathrm{~min}$ at $94^{\circ} \mathrm{C}$. Each cycle consisted of denaturation at $94^{\circ} \mathrm{C}$ for $1 \mathrm{~min}$; annealing at $36^{\circ} \mathrm{C}$ for $1 \mathrm{~min}$; extension at $72^{\circ} \mathrm{C}$ for $2 \mathrm{~min}$ and final extension at $72^{\circ} \mathrm{C}$ for $10 \mathrm{~min}$ (Williames, et al. 1990). RAPD's fragments scored as present/absent. Fragment scoring, and lane matching performed automatically on digital images of the gels, using Phoretix 1D advanced Version 4.00 (Phoretix International, Newcastle upon Tyne, UK). All but the faintest bands scored, where necessary scores and 
matches corrected manually. The clustering methods UPGMA, WPGMA, Complete-link, and Single-link were applied in all possible combinations with the similarity coefficients Dice, Jaccard and simple matching. Rohlf (2000) describes clustering methods and similarity coefficients.

Table 1. The nucleotide sequences of primers used for RAPD analysis

\begin{tabular}{|c|c|c|}
\hline Code & Primer code & Sequence (5`-3’) \\
\hline 1 & OPA-05 & 5`- AGG GGT CTT G-3 \\
\hline 2 & OPA-10 & 5-GTG ATC GCA G-3` \\
\hline 3 & OPA-15 & 5'-TTC CGA ACC C-3’ \\
\hline 4 & OPC-12 & 5-TGT CAT CCC C-3 \\
\hline 5 & OPC-16 & 5-CAC CAT CCA G-3` \\
\hline 6 & OPD-04 & 5'-TCT GGT GAG G-3` \\
\hline 7 & OPD-11 & 5-AGC GCC ATT G-3 \\
\hline 8 & OPR-01 & 5-CTT CCG CAG T-3` \\
\hline 9 & OPR-02 & 5-GGT GCG GGA A-3 \\
\hline 10 & OPR-05 & 5-GAC CTA GTG G-3 \\
\hline
\end{tabular}

The completely randomized design with three replications was used to outline this work. The attained data was statistically analyzed as a factorial experiment using Co-state program version 3.6. The least significant difference (L.S.D.) was calculated to compare treatment means at 0.05 level of probability. The percent of polymorphic $(\mathrm{P})$ was calculated using the formula: $\mathrm{P}=100(\mathrm{p} / \mathrm{n})$ where $p$ is the number of polymorphic loci and $\mathrm{n}$ is the total number of loci. A locus is polymorphic if the frequency of the allele is less than 0.95 .

\section{RESULTS AND DISCUSSION}

\section{a- Morphological variations of cotton varieties}

Morphological variations were calculated during the early growth stage ( 30, 60 and 90 days) such as plant height $(\mathrm{cm})$, root length $(\mathrm{cm})$, number of leaves/plant and bolls number/plant. Data in Table (2) for plant height $(\mathrm{cm})$ showed that Giza 86 had have the highest mean values comparing with the other cotton varieties during the three-reading time after 30,60 and 90 days. The means were $42.6,49.3$ and $63.7 \mathrm{~cm}$, respectively. While Giza 88 and 90 showed the lowest means as recorded in Table (2) by values 32.2, 34.9; $39.7,35,9,41.1$ and $41.6 \mathrm{~cm}$, in respect. High significant variations were observed between the tested varieties. The general average for the cotton plant height $(\mathrm{cm})$ ranged from $\sim 37$ to $52 \mathrm{~cm}$ (Table 2). The lowest mean was 37.4 and $37.66 \mathrm{~cm}$ for Giza 90 and 88, while the highest mean was $51.86 \mathrm{~cm}$ recorded to Giza 86. By comparing between the extra-long staple length cotton varieties (Giza 88 and 92) with the long staple length (Giza 86, 90 and 95), the data showed that the first categories showed the lowest general mean 41.46 $\mathrm{cm}$ and the other one recorded the highest mean was $43.64 \mathrm{~cm}$ (Table 2). The general mean of root length (cm) for both Egyptian cotton categories ranged from 12.46 to $19.13 \mathrm{~cm}$ (Table 2). The highest mean was $19.13 \mathrm{~cm}$ recorded to Giza 86 and the lowest mean was $12.46 \mathrm{~cm}$ for Giza 90. The cotton variety Giza 86 showed the highest root length during the different growth stage time that were $13.8,20.2$ and $23.4 \mathrm{~cm}$ and Giza 90 showed almost the same average for this character (Table 2). no significant variations were observed between the Giza 92 and 86 which recorded under extra-long staple length cotton (Table 2). The third morphological character is number of leaves/plant which was the highest in Giza 86 by 10.63 as general mean compared with 9.56 leaves/plant as the lowest value in Giza 90 (Table 2). no significant variations were observed between the first and second reading in plant growth stage, while with the increase in time, data showed significant variations between the two cotton categories. The general mean values ranged from 9.56 (Giza 90) to 10.63 (Giza 86) leaves/plant (Table 2). Data in Table 2 for bolls number/plant showed significant variations between the different cotton growth stages. The general average ranged from 1.33 to 2.05 bolls/plant. The highest bolls number recorded to Giza 95 by 2.46 boll and the lowest variety was Giza 86 which showed 1.33 bolls/plant after 90 days of growth stage, followed by Giza 88 by 1.76 bolls. The lowest bolls number for all cotton varieties may be due to the experiment was sown in pots (Table 2).

\section{b- Morphological variations of cotton varieties}

Morphological variations were calculated during the early growth stage ( 30, 60 and 90 days) such as plant height $(\mathrm{cm})$, root length $(\mathrm{cm})$, number of leaves/plant and bolls number/plant. Data in Table (2) for plant height $(\mathrm{cm})$ showed that Giza 86 had have the highest mean values comparing with the other cotton varieties during the three-reading time after 30,60 and 90 days. The means were 42.6, 49.3 and $63.7 \mathrm{~cm}$, respectively. While Giza 88 and 90 showed the lowest means as recorded in Table (2) by values 32.2, 34.9; $39.7,35,9,41.1$ and $41.6 \mathrm{~cm}$, in respect. High significant variations were observed between the tested varieties. The general average for the cotton plant height $(\mathrm{cm})$ ranged from $\sim 37$ to $52 \mathrm{~cm}$ (Table 2). The lowest mean was 37.4 and $37.66 \mathrm{~cm}$ for Giza 90 and 88 , while the highest mean was $51.86 \mathrm{~cm}$ recorded to Giza 86. By comparing between the extra-long staple length cotton varieties (Giza 88 and 92) with the long staple length (Giza 86, 90 and 95), the data showed that the first categories showed the lowest general mean 41.46 $\mathrm{cm}$ and the other one recorded the highest mean was $43.64 \mathrm{~cm}$ (Table 2). 
Table 2. Mean values of morphological cotton properties

\begin{tabular}{|c|c|c|c|c|c|c|c|c|c|c|c|c|c|c|c|c|}
\hline \multirow{3}{*}{$\begin{array}{l}\text { Cotton } \\
\text { cultivars }\end{array}$} & \multicolumn{4}{|c|}{ Plant height $(\mathrm{cm})$} & \multicolumn{4}{|c|}{ Root length $(\mathrm{cm})$} & \multicolumn{4}{|c|}{ Leaves number } & \multicolumn{4}{|c|}{ Bolls number } \\
\hline & 30 & 60 & 90 & Ave. & 30 & 60 & 90 & Ave. & 30 & 60 & 90 & Ave. & 30 & 60 & 90 & Ave. \\
\hline & & days & & & & days & & & & days & & & & days & & \\
\hline Giza 92 & $37.8 \mathrm{~b}$ & $45.1 \mathrm{~b}$ & $52.6 \mathrm{~b}$ & 45.16 & $11.4 \mathrm{~b}$ & $12.5 \mathrm{~b}$ & $14.2 \mathrm{~b}$ & 12.7 & $7.3 \mathrm{a}$ & $9.5 \mathrm{a}$ & $12.3 \mathrm{c}$ & 9.70 & $1.8 \mathrm{a}$ & $1.2 \mathrm{c}$ & $2.7 \mathrm{ab}$ & 1.90 \\
\hline Giza 88 & $32.2 \mathrm{c}$ & $39.7 \mathrm{c}$ & $41.1 \mathrm{c}$ & 37.66 & $11.0 \mathrm{~b}$ & $18.4 \mathrm{a}$ & $14.7 \mathrm{~b}$ & 14.7 & $4.5 \mathrm{c}$ & $6.5 \mathrm{c}$ & $14.2 \mathrm{bc}$ & 8.40 & $0.0 \mathrm{c}$ & $2.3 b$ & $2.0 \mathrm{~b}$ & 1.76 \\
\hline Giza 86 & $42.6 \mathrm{a}$ & $49.3 \mathrm{a}$ & $63.7 \mathrm{a}$ & 51.86 & $13.8 \mathrm{a}$ & $20.2 \mathrm{a}$ & $23.4 \mathrm{a}$ & 19.13 & $5.7 \mathrm{~b}$ & $9.0 \mathrm{a}$ & $17.2 \mathrm{a}$ & 10.63 & $1.8 \mathrm{a}$ & $0.0 \mathrm{~d}$ & $2.2 \mathrm{~b}$ & 1.33 \\
\hline Giza 95 & $36.2 \mathrm{bc}$ & $36.7 \mathrm{~d}$ & $51.9 \mathrm{~b}$ & 41.6 & $12.1 \mathrm{ab}$ & $15.4 \mathrm{a}$ & $18.5 \mathrm{bc}$ & 15.33 & $6.0 \mathrm{~b}$ & $8.2 \mathrm{~b}$ & $14.8 \mathrm{~b}$ & 9.66 & $1.7 \mathrm{a}$ & $3.2 \mathrm{a}$ & $3.5 \mathrm{a}$ & 2.46 \\
\hline Giza 90 & $34.9 \mathrm{bc}$ & $35.9 \mathrm{~d}$ & $41.6 \mathrm{c}$ & 37.46 & $10.4 \mathrm{~b}$ & $13.4 \mathrm{~b}$ & $13.6 \mathrm{c}$ & 12.46 & $5.5 \mathrm{~b}$ & $9.2 \mathrm{a}$ & $14.0 \mathrm{bc}$ & 9.56 & $1.2 \mathrm{~b}$ & $2.2 \mathrm{~b}$ & $2.8 \mathrm{ab}$ & 2.06 \\
\hline LSD at 0.05 & 4.34 & 1.77 & 5.35 & & 1.83 & 3.92 & 1.33 & & 0.99 & 0.78 & 2.20 & & 0.47 & 0.47 & 0.91 & \\
\hline
\end{tabular}

The general mean of root length $(\mathrm{cm})$ for both Egyptian cotton categories ranged from 12.46 to $19.13 \mathrm{~cm}$ (Table 2). The highest mean was $19.13 \mathrm{~cm}$ recorded to Giza 86 and the lowest mean was $12.46 \mathrm{~cm}$ for Giza 90. The cotton variety Giza 86 showed the highest root length during the different growth stage time that were 13.8, 20.2 and $23.4 \mathrm{~cm}$ and Giza 90 showed almost the same average for this character (Table 2). no significant variations were observed between the Giza 92 and 86 which recorded under extra-long staple length cotton (Table 2). The third morphological character is number of leaves/plant which was the highest in Giza 86 by 10.63 as general mean compared with 9.56 leaves/plant as the lowest value in Giza 90 (Table 2). no significant variations were observed between the first and second reading in plant growth stage, while with the increase in time, data showed significant variations between the two cotton categories. The general mean values ranged from 9.56 (Giza 90) to 10.63 (Giza 86) leaves/plant (Table 2). Data in Table 2 for bolls number/plant showed significant variations between the different cotton growth stages. The general average ranged from 1.33 to 2.05 bolls/plant. The highest bolls number recorded to Giza 95 by 2.46 boll and the lowest variety was Giza 86 which showed 1.33 bolls/plant after 90 days of growth stage, followed by Giza 88 by 1.76 bolls. The lowest bolls number for all cotton varieties may be due to the experiment was sown in pots (Table 2).

Mean values within each column designated by the same letter are not significantly different

\section{c- Technological variations of cotton varieties (HVI Fiber characteristics)}

Data in Table (3) cleared the mean values of the fiber properties, as influenced by cotton variety. Results attained indicated that there were a significant differs on fiber properties due to cotton variety. The highest mean values $(35.79 \mathrm{~mm}$ and $89.26 \%$ ) for upper half mean length (UHML) and length uniformity \% of extra-long cotton variety Giza 88 . On the other side, the lowest mean values for upper half mean length (UHML) and length uniformity were recorded from long cotton varieties Giza 95 and Giza 90. Concerning the short fiber percentage, could be noticed that the long cotton varieties Giza 95 and Giza 90 recorded the highest mean values (81.93 and $83 \%$ ), respectively. From Table (3) worthy to mention that the highest mean values (46.5 g/tex and 6.06\%) of fiber strength and elongation \% were ginned from variety Giza 92 and Giza 90, respectively. Meanwhile, the lowest mean values $(32.93 \mathrm{~g} /$ tex and $3.56 \%)$ for the same traits were showed from variety Giza 90 and Giza 88, respectively. Respecting data in Table (3) could be cleared that the cotton variety Giza 86 recorded the highest mean values $(0.89 \%, 4.61$ and $77.80 \%)$ of fiber maturity \%, micronaire reading and reflectance degree ( $\mathrm{Rd} \%)$. Contrary, the lowest mean values for the same traits, $(0.86 \%, 3.66$ and $67.56 \%)$, respectively. The highest yellowness degree 12.96 was attained from Giza 95, while the lowest mean value 8.93 was cleared from Giza 86. These results could be explained on the basis that the extra-long staple cotton varieties i.e., Giza 92 and Giza 88 contain the healthy fiber properties and produce the best yarn quality compared with the long staple cotton varieties. Data in Figure 1 showed the similarity and distance between the extra-long staple cotton varieties (Giza 92 and Giza 88) and long staple cotton varieties (Giza 68, 90 and 95). The cluster divided into two groups, the first one includes both Giza 88 and 88 together by $100 \%$ similarity and the other group includes the other three cotton varieties by $100 \%$ similarity. The main cluster divided into two clusters by $98 \%$ for all cotton varieties. Morphological or technological parameters can have affected by environmental effects, so the similarity was very high between both cotton categories. These data are compatible with isozyme data which proved the same results for the five cotton varieties with 100 genetic similarity between the extra-long staple cotton, in the other hand $100 \%$ between the long staple cotton varieties, although, the cluster was divided by $62 \%$.

These results in line with those Abd El-Glil (2001) reported that fiber length parameters; i.e., $(2.5 \%, 50 \%$ span length and length uniformity ratio), reflectance degree $(\mathrm{Rd} \%)$, degree of yellowness $(+\mathrm{b})$, fiber maturity 
ratio, fiber bundle strength (g/tex), elongation $(\%)$ and toughness $(\mathrm{g} / \mathrm{tex})$ were significantly affected by cotton varieties. Also, our results are agreeing with Richard et al. (2006) and Yeates et al., (2010) who reported that cotton fiber quality is the result of an interaction between genetic and environmental effects. The current results are agreeing with Batisha (2005), reported that staple length, reflectance degree $(\mathrm{Rd} \%)$, yellowness $(+b)$, proportion of maturity (PM), hair weight bundle strength and elongation \% were significantly affected by the cotton cultivar. Also, Foulk (2008), reported that cotton quality is affected by cotton cultivar and growing conditions. Results in the same trend with Ibrahim (2010) who attained that the extra-long staple cultivar,

Table 3. Mean values of technological cotton fibre properties

\begin{tabular}{|c|c|c|c|c|c|c|c|c|c|}
\hline $\begin{array}{l}\text { Cotton } \\
\text { varietie } \\
\mathrm{S}\end{array}$ & $\begin{array}{c}\text { UHML } \\
(\mathbf{m m})\end{array}$ & $\begin{array}{c}\text { Length } \\
\text { uniformit } \\
\mathbf{y} \\
(\%) \\
\end{array}$ & $\begin{array}{c}\text { Short } \\
\text { fiber } \\
\%\end{array}$ & $\begin{array}{c}\text { Fiber } \\
\text { strength } \\
\text { (g/tex) }\end{array}$ & $\begin{array}{c}\text { Fiber } \\
\text { elongation } \\
\%\end{array}$ & $\begin{array}{c}\text { Maturit } \\
\text { y } \%\end{array}$ & $\begin{array}{c}\text { Micronair } \\
\text { e } \\
\text { reading }\end{array}$ & $\begin{array}{c}\text { Reflectanc } \\
\text { e degree } \\
(\text { Rd \%) }\end{array}$ & $\begin{array}{c}\text { Yellownes } \\
\text { s degree } \\
(+b)\end{array}$ \\
\hline Giza 92 & $33.93^{b}$ & $88.66^{\mathrm{a}}$ & $5.63^{b}$ & $46.5^{\mathrm{a}}$ & $4.8^{\mathrm{b}}$ & $0.87^{b}$ & $4.01^{b}$ & $75.50^{b}$ & $8.20^{\mathrm{d}}$ \\
\hline Giza 88 & $35.79^{\mathrm{a}}$ & $89.26^{\mathrm{a}}$ & $5.53^{\mathrm{b}}$ & $40.53^{\mathrm{b}}$ & $3.56^{\mathrm{c}}$ & $0.88^{\mathrm{b}}$ & $4.11^{\mathrm{b}}$ & $69.06^{\mathrm{c}}$ & $11.26^{\mathrm{b}}$ \\
\hline Giza 86 & $33.22^{\mathrm{b}}$ & $88.83^{\mathrm{a}}$ & $5.9^{\mathrm{b}}$ & $43.86^{\mathrm{ab}}$ & $4.43^{\mathrm{b}}$ & $0.89^{\mathrm{a}}$ & $4.61^{\mathrm{a}}$ & $77.80^{\mathrm{a}}$ & $8.93^{c}$ \\
\hline Giza 95 & $27.04^{\mathrm{c}}$ & $81.93^{\mathrm{b}}$ & $8.86^{\mathrm{a}}$ & $33.03^{\mathrm{c}}$ & $5.06^{\mathrm{b}}$ & $0.86^{\mathrm{c}}$ & $3.66^{\mathrm{c}}$ & $67.56^{\mathrm{d}}$ & $12.96^{\mathrm{a}}$ \\
\hline Giza 90 & $28.23^{\mathrm{c}}$ & $83.00^{\mathrm{b}}$ & $8.13^{\mathrm{a}}$ & $32.93^{\mathrm{c}}$ & $6.06^{\mathrm{a}}$ & $0.87^{\mathrm{b}}$ & $4.67^{\mathrm{a}}$ & $66.63^{\mathrm{d}}$ & $11.60^{\mathrm{b}}$ \\
\hline LSD.0.05 & 1.39 & 2.26 & 1.30 & 4.81 & 0.84 & 0.009 & 0.32 & 1.43 & 0.34 \\
\hline
\end{tabular}

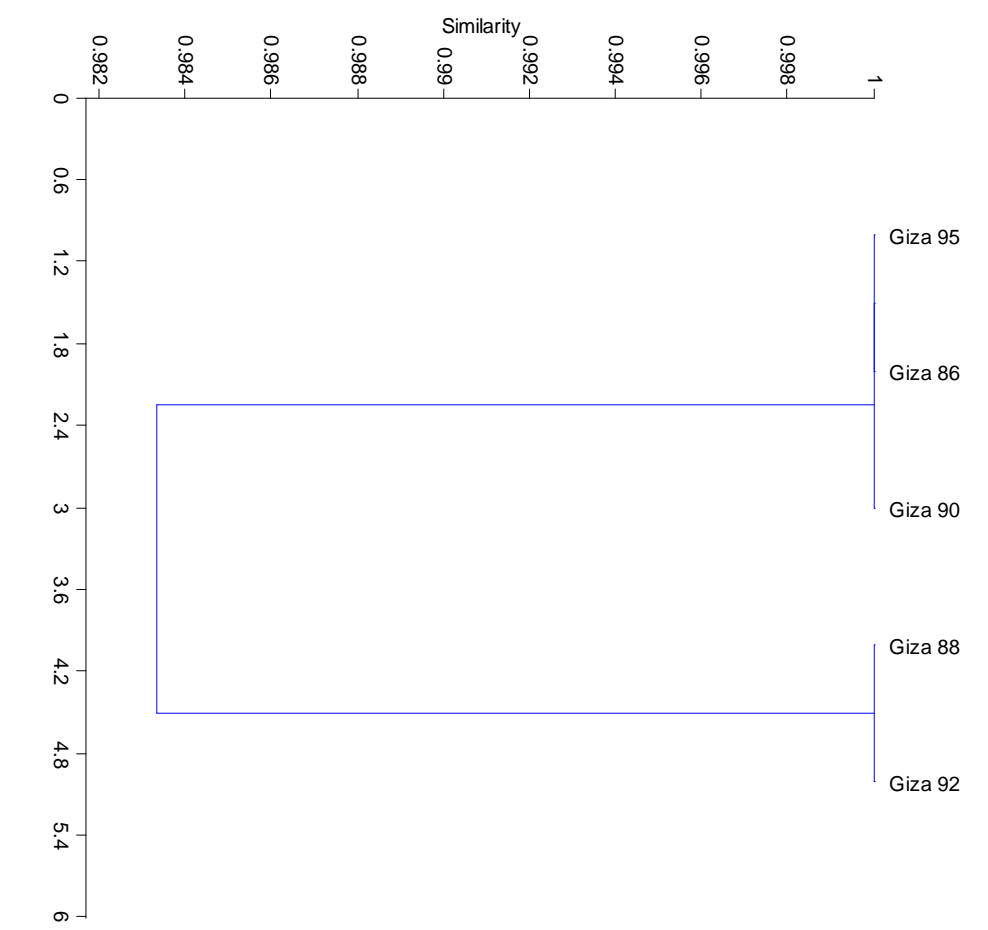

Figure 1. Similarity and genetic distance of some Egyptian cotton varieties based on technological fiber properties analysis (HVI Fiber characteristics)
Giza 88 surpassed the long staple cultivar, Giza 86 in upper half mean length (UHML), mean length (mm), uniformity index, fiber bundle trength $(\mathrm{g} / \mathrm{tex})$ and fiber elongation (\%). while, the long staple cotton cultivar, Giza 86 recorded the highest mean values concerning micronaire value, maturity $(\%)$ and reflectance degree (Rd \%). Finally, Ibrahim (2013), found that the extralong staple cotton variety Giza 45 and high lint cotton grade recorded the highest mean values of the most importance of fiber and yarn properties and the lowest value of short fiber content $(\%)$ and yarn evenness $\mathrm{CV}$ $\%$ and vice versa for the long staple cotton variety Giza 80 and low lint cotton grade. 


\section{Mean values within each column designated by the same letter are not significantly different}

\section{d- Biochemical assay (Iso-enzymes)}

Peroxidase iso-enzyme assay was applied as the most appropriate technique for the evaluation of cotton varieties, and classified peroxidase patterns were ascribed to different phenotypes. Isozyme is an important tool to detect the variation between different species or varieties. Peroxidase activity was assessed for the five cotton varieties collected from Egypt as tool calculate the genetic relationship among cotton varieties. In contrast, as shown in Figure 2, Peroxidase isozymes exhibited a wide range of variability among the different cotton varieties. In total of 5 loci, one anodal and four cathodal loci were detected. One anodal (Pex.1a) was found as common band for all the varieties for the positive charge. While two cathodal (pex 1c, and pex 2c) were found to the negative charge. Pex.c3 and Pex.c4 were found as unique bands for three cotton variety (1) Giza 95, (2) Giza 9. and (3) Giza 86. Data showed 21 loci for all cotton varieties (staple and extra-long staple length) Giza 95, Giza 90 and Giza 86 recorded 5 loci for each, while Giza 92 and (3) Giza 88 showed three loci based on enzyme activity. Data for genetic matrix data showed that the staple long staple length cotton i.e. Giza 95, Giza 90 and Giza 86 gave $100 \%$ genetic similarity comparing with the other extra-long staple length cotton varieties Giza 92 and 88 which showed $75 \%$. These data were obtained also in Figure $r$ which indicated that all the cotton varieties clustered into two main cluster with $61 \%$ genetic similarity. The first cluster includes three cotton staple length varieties Giza 86, 90 and 95 by 100 similarity and the other cluster includes the twocotton extra-long staple length varieties Giza 92 and 88 $(100 \%)$.

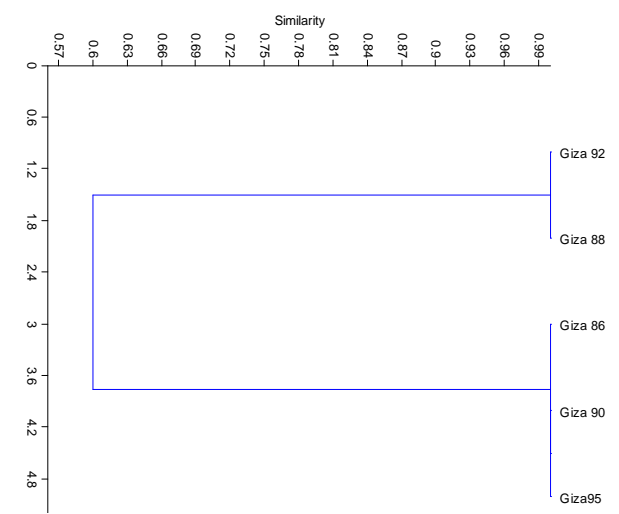

Isozyme loci have been used as markers in several genetic studies, such as genetic diversity in Brassica juncea (Persson et al., 2001), and isozyme markers as seed coat color (Rahman, 2002). Peroxidases are enzymes related to polymer synthesis in cell wall (Bowles, 1990), as well as in the prevention of oxidative damage caused by environmental stress to the membrane lipids. It was found that salt stress increased peroxidase band intensity. Hong et al. (2005) showed that peroxidases are common and important indices for evaluating wheat redox, its activity display higher antioxidative abilities, reflecting higher resistance to drought. Peroxidase are enzymes related to polymer synthesis in cell wall (Bowles, 1990), as well as in the prevention of oxidative damage caused by environmental stress to the membrane lipids (Kalir et al., 1984). Plant peroxidase have been used as biochemical markers for various types of biotic and Abiotic stresses due to their role in very important physiological processes, like control of growth by lignification's, cross linking of pectin's and structural proteins in cell wall, catabolism of auxins (Gaspar et al., 1982). Catalases and superoxide dismutase are the most efficient antioxidant enzymes (Scandalios, 1984). The expression of specific catalase isoenzymes is important and Isoenzyme Profiles of Peroxidase, Catalase and bcritical against oxidative stress induced by a given environmental stress (Scandalios, 1994). The modifications of gene expression due to environmental stress are a common response in the metabolism of plant cells. Gene activation due to environmental stimuli plays an extremely important role in the adaptation of plants to unfavorable conditions and promotes the appearance of specific proteins (Naqvi et al. 1995). In addition, proteins and isozyme polymorphisms are good indicators of response to biotic and abiotic stresses (Doebley, 1989).

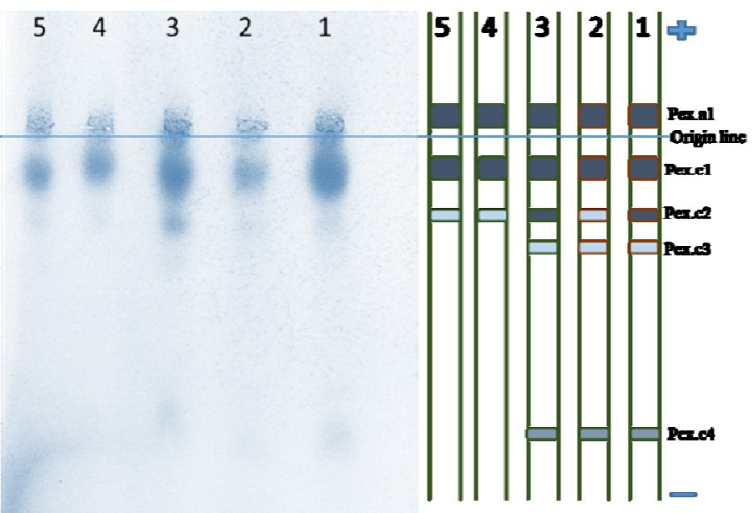

Figure 2. Zymograme of peroxidase isozymes in Egyptian cotton varieties (1) Giza 95, (2) Giza 90, (3) Giza 86, (4) Giza 92 and (5) Giza 88 


\section{e- Random amplified polymorphism DNA (RAPD- PCR)}

Ten, RAPD-PCR primers were used in screening the diversity between different genomic-DNA of cotton varieties. For each primer-DNA combination, the amplification was repeated at least twice. As shown in Table 4, the number of reproducible bands/primer varied between 13 for primer OPR-05 and 46 for primer OPR-02 with a total of 312 amplification fragments (Table 4). The results in Table (4) clearly indicated that in all studied cotton varieties, $224(71 \%)$ of the 312 fragments were polymorphic and 88 (29\%) were monomorphic. In the meantime, all used primers generated 25 specific markers (Table 4). The largest number of these markers was specific for Giza 9 . by 75 fragments and the lowest number was recorded to Giza 9 r by 52 fragments. Furthermore, eight specific large bands were observed in the Giza 95 (Table 4). The data for Giza 95 cultivar, detect 72 amplification fragments with eight specific bands. Within the 75 fragments, 52 fragments were polymorphic by $72 \%$ genetic polymorphism. While, for the next cotton cultivar Giza 9. the data recorded 75 fragments, 55 were polymorphic and 20 were monomorphic with $73 \%$ genetic polymorphism (Table 4).

Fifty fragments were polymorphic and twenty were monomorphic in Giza 86 which showed $71 \%$ genetic similarity (Table 4). In the other hand both Giza 92and 88 recorded the lowest amplification fragments which were 52 and 54, respectively. The genetic similarity was 62 and $61 \%$, in respect by monomorphic bands were 32 and 33 (Table 4). In general varieties Giza 95, 9. and 86 detect the highest amplification fragments ranged from 70 to 75 , while Giza 88 and 92 showed the lowest number was from 52 to 54 (Table 4). Data for the primer OPA-05 showed in total 27 fragments ranged from 300 to $2000 \mathrm{bp}$. Nine amplification fragments were polymorphic by $33 \%$ and 18 fragments were monomorphic (Table 4). The same genetic polymorphism was recorded to OPA-10 (33\%) which showed 29 fragments. The bands ranged from 350 to 1500 bp (Table 4). The third primer in this group OPA15 showed 38 amplification fragments and 26 were polymorphic by $68 \%$, these fragments ranged from 400 to $2000 \mathrm{bp}$ as shown in Table 4. The next primers group were OPR1, OPR-2 and OPR-5 which recorded amplification fragments 40, 46 and 13, in respect. 32, 43 and 10 fragments were polymorphic by 80,93 and $76 \%$, respectively (Table 4). Four specific fragments were detected for all the primers in this group. The length of bands ranged from 300-1500, 400-700 and
200-2350 bp, in respect (Table 4). OPR-05 showed the lowest primer which detect the lowest fragments 13 . OPC-12 and 16 primers showed 26 and 24 amplification fragments in respect (Table 4). 19 and 24 fragments were polymorphic by $73 \%$. The molecular weight of these fragments ranged from 350-1200 and 200-1600 bp (Table 4). Five specific fragments/markers were detected to OPC-16 and no markers was detected for OPC-12.

Finally, the primer group OPD-04 and 11, showed 41 and 26 fragments which ranged from 300-700 and 250-2000 bp, respectively (Table 4). For OPD-04 the genetic polymorphism was $100 \%$ two specific markers were detected, while in OPD-11 two specific markers were detected with $76 \%$ genetic polymorphism (Table 4).

Our results were agreeing with many different works which used RAPD markers in many different crops to detect the genetic diversity such as in wheat and Fig (Mohamed etal. 2017) Manifesto et al. (2001) found some specific RAPD marker while examining genetic diversity in spring wheat cultivars grown in the Yaqui Valley of Mexico and the Punjab of Pakistan. Also, Sajida Bibi et al. (2009) indicated many specific RAPD markers among commercially grown lines of wheat in Pakistan. Due to different obtained data from the studied cultivars using RAPD marker further studies will be necessary to identify the genetic constitutions of specific markers. Molecular markers provide a good estimate of genetic diversity since they are independent of confounding effects by environmental factors (Powell et al. 1996). This will have led to identify their interrelation especially with the biotic and abiotic stress to enhance the domesticated wheat structure. Hoping to use them as gene constructs for improving these cultivars using their relatives of wild wheat. These results were agreeing with Rana et al. (2005) who reported a wider genetic diversity $(30-87 \%)$ within $G$. hirsutum breeding lines using AFLP markers. Our results were agreeing with Sapkal et al. (2011) who used SSR and RAPD markers for calculate the genetic similarity and reported moderately high level of genetic diversity (57\%) for 91 Upland cotton accessions with genetic male sterility maintainer and restorer properties. Also, our results in the line with de Almeida et al. (2009) who studied the molecular diversity level of $G$. barbadense populations in situ preserved in the two states of Brazil using SSR markers of plant populations in these two states revealed high homozygosity in each genotype tested and high total genetic diversity $(\mathrm{He}=39 \%)$ in $G$. barbadense populations studied and high level of population 
Table 4. Number of amplified fragments and specific marker for cotton varieties based on RAPD analysis

\begin{tabular}{|c|c|c|c|c|c|c|c|c|c|c|c|c|}
\hline \multirow{2}{*}{\multicolumn{2}{|c|}{ Varieties }} & \multirow{3}{*}{$\begin{array}{r}\text { Total } \\
72\end{array}$} & \multicolumn{10}{|c|}{ Primers } \\
\hline & & & \multirow{2}{*}{$\begin{array}{c}\text { OPA-05 } \\
10\end{array}$} & \multirow{2}{*}{$\begin{array}{c}\text { OPA-10 } \\
8\end{array}$} & \multirow{2}{*}{$\frac{\text { OPA-15 }}{7}$} & \multirow{2}{*}{$\frac{\text { OPR-01 }}{9}$} & \multirow{2}{*}{$\begin{array}{c}\text { OPR-02 } \\
10\end{array}$} & \multirow{2}{*}{$\begin{array}{c}\text { OPR-5 } \\
5\end{array}$} & \multirow{2}{*}{$\frac{\text { OPC-12 }}{6}$} & \multirow{2}{*}{$\frac{\text { OPC-16 }}{5}$} & \multirow{2}{*}{$\frac{\text { OPD-04 }}{7}$} & \multirow{2}{*}{$\frac{\text { OPD-11 }}{5}$} \\
\hline & $\mathbf{A F}$ & & & & & & & & & & & \\
\hline $\begin{array}{c}\text { Giza } \\
05\end{array}$ & Sm & 8 & 0 & 0 & 1 & 3 & 0 & 1 & 0 & 1 & 2 & 0 \\
\hline & PF (\%) & $52(72)$ & $3(30)$ & $3(37)$ & $3(42)$ & $6(66)$ & $9(90)$ & $2(40)$ & $5(83)$ & $4(80)$ & $4(57)$ & $3(60)$ \\
\hline \multirow{3}{*}{$\begin{array}{c}\text { Giza } \\
90\end{array}$} & $\mathbf{A F}$ & 75 & 8 & 9 & 11 & 8 & 9 & 6 & 8 & 2 & 8 & 6 \\
\hline & Sm & 6 & 1 & 0 & 2 & 0 & 0 & 1 & 0 & 0 & 0 & 0 \\
\hline & PF (\%) & $55(73)$ & $2(25)$ & $2(22)$ & $11(100)$ & $5(63)$ & $8(89)$ & $3(50)$ & $8(100)$ & $2(100)$ & $5(63)$ & $4(67)$ \\
\hline \multirow{3}{*}{$\begin{array}{c}\text { Giza } \\
86\end{array}$} & $\mathbf{A F}$ & 70 & 5 & 5 & 9 & 9 & 10 & 3 & 7 & 8 & 9 & 5 \\
\hline & Sm & 5 & 0 & 0 & 0 & 1 & 1 & 0 & 0 & 3 & 0 & 0 \\
\hline & PF (\%) & $50(71)$ & $1(20)$ & $1(20)$ & $9(100)$ & $6(67)$ & $9(90)$ & $2(67)$ & $7(100)$ & $8(100)$ & $6(67)$ & $3(60)$ \\
\hline \multirow{3}{*}{$\begin{array}{c}\text { Giza } \\
92\end{array}$} & $\mathbf{A F}$ & 52 & 5 & 5 & 7 & 7 & 7 & 2 & 4 & 5 & 4 & 5 \\
\hline & Sm & 2 & 0 & 0 & 0 & 0 & 1 & 0 & 0 & 0 & 0 & 0 \\
\hline & PF (\%) & $32(62)$ & $1(20)$ & $1(20)$ & $7(100)$ & $4(57)$ & $7(100)$ & $1(50)$ & $4(100)$ & $5(100)$ & $4(100)$ & $3(60)$ \\
\hline \multirow{3}{*}{$\begin{array}{c}\text { Giza } \\
88\end{array}$} & $\mathbf{A F}$ & 54 & 4 & 6 & 7 & 7 & 7 & 3 & 2 & 5 & 8 & 5 \\
\hline & $\mathrm{Sm}$ & 6 & 0 & 0 & 1 & 0 & 2 & 1 & 0 & 1 & 0 & 0 \\
\hline & PF (\%) & $33(61)$ & Zero & $2(33)$ & $7(100)$ & $4(57)$ & $6(86)$ & $2(67)$ & $2(100)$ & $5(100)$ & $5(63)$ & $3(60)$ \\
\hline \multirow{3}{*}{ Total } & $\mathbf{A F}$ & 312 & 27 & 29 & 38 & 40 & 46 & 13 & 26 & 24 & 41 & 26 \\
\hline & Sm & 25 & 1 & 0 & 4 & 4 & 4 & 3 & 0 & 5 & 2 & 2 \\
\hline & PF (\%) & $224(71)$ & $9(33)$ & $11(37)$ & $26(68)$ & $32(80)$ & $43(93)$ & $10(76)$ & $19(73)$ & $24(100)$ & $41(100)$ & $20(76)$ \\
\hline
\end{tabular}

*AF= No. Amplified Fragments

*Sm: Specific marker fragments

*PF $(\%)$ : Polymorphic fragments and Percentages of polymorphism are in parentheses.

differentiation $(\mathrm{Fst}=36 \%)$ between cotton plants from these two Brazilian states. The results in a line with Rahman et al. (2008) who studied 32 G. arboreum accessions from Pakistan using RAPD markers and found up to $53 \%$ genetic diversity between studied accessions with very narrow diversity within cultivated G. arboreum accessions compared to non-cultivated ones. The results are agreed with Bardakci and Skibinski, (1999) showed that one cause of RAPD polymorphisms is chromosomal rearrangements such as insertions/deletions. Therefore, amplified products from the same alleles in a heterozygote differ in length and will be detected as presence or absence of bands in the RAPD profile. In fact, we can have concluded that random amplified polymorphic DNA (RAPD) analysis has proved useful for estimating genetic diversity particularly to assist in the conservation of rare species and plant genetic resources (Anderson and Fairbanks, 1990).

\section{f- Genetic similarity of cotton varieties based on different markers}

Data in Figure 3 show the genetic similarity of the cotton varieties based on morphological, technological, biochemical and molecular markers. Four morphological, nine technological characters, one enzyme activity and ten random amplified polymorphism DNA were used to calculate the genetic similarity and diversity of the two common cotton categories in Egypt (staple and extra-long staple length). The cluster divided into two main cluster by $62 \%$ genetic similarity. The first cluster includes two cotton varieties i.e. Giza 90 and 95 by $77 \%$ genetic similarity and the other cluster divided into two groups with $69 \%$ genetic similarity which includes Giza 92 in separate group, while the other one had Giza 86 and 88 with $81 \%$ genetic similarity. The cluster for cotton varieties recorded the extra-long staple length (over 13/8-inch fiber length) in one group (Giza 88 and 92 ) by $69 \%$ and the two long staple length $\left(1 \frac{1}{4}-1 \frac{3}{8}\right.$ inch) fiber length in other cluster (Giza 90 and 95) by 77\%, while Giza 86 shard the first cluster by $82 \%$ genetic similarity. From these data, we can provide that there are high genetic variations between the two-cotton type in Egypt and these found could be useful in breeding program in the future. Cotton productivity and the future of cotton breeding efforts tightly depend on the level of the genetic diversity of cotton gene pools and its effective exploitation in cotton breeding programs. Elucidating the details of genetic diversity is also very important to determine timeframe of cotton agronomy, develop a strategy for genetic gains in breeding, and conserve existing gene pools of cotton.

The present results in accordance agreeing with that obtained by Erkılınç and Karaca (2005) who analyzed the genetic variation in 36 Turkish cotton varieties using microsatellites and identified 2 distinct genotypes. Our results confirm those findings, Bardak and B?lek 
(2012) used 7 commercial Turkish cotton genotypes to analyze the genetic diversity of diploid and tetraploid cottons, and reported that genetic distance among $G$. hirsutum L. genotypes was between 0.04 and 0.23 . Surgun et al. (2012) also analyzed 9 Turkish cotton varieties by RAPD markers and detected the rate of polymorphism among the genotypes to be $18.1 \%$.

The lack of genetic diversity is implicated in the successful breeding program depends on the slowing of progress in developing new cotton cultivars complete knowledge and understanding of the genetic with improved yield and quality potential, as well as diversity within and among genetic resources of the stress resistance. To broad the cotton genetic available germplasm and enable plant breeders to base, this may be accomplished by collection of available choose parental sources that will generate diverse germplasm or developing inter and intra-specific hybrids. The level of genetic diversity of crop species is an essential element of sustainable crop production in agriculture, including cotton. The amplitude of genetic diversity of Gossypium species is exclusively wide, encompassing wide geographic and ecological niches. Assessment of genetic markers and diversity form an integral part of any successful breeding program. Morphological features are indications of the genotype but are represented by only a few loci because there are not a large enough number of characters available. Moreover, they can also be affected by environmental factors and growth practices. To overcome the limitations associated with morphological markers, various biochemical and molecular marker techniques have come up in recent years. Biochemical markers such as isozymes have been used to study the genetic distances and estimate the level of genetic variability of cotton varieties and accessions (Saif et al 2017; Abdel-Tawab et al., 1990 \& 1993; Melchinger et al., 1991; Wendel et al., 1992; Sukumar and Allan, 1998; Farooq et al., 1999).

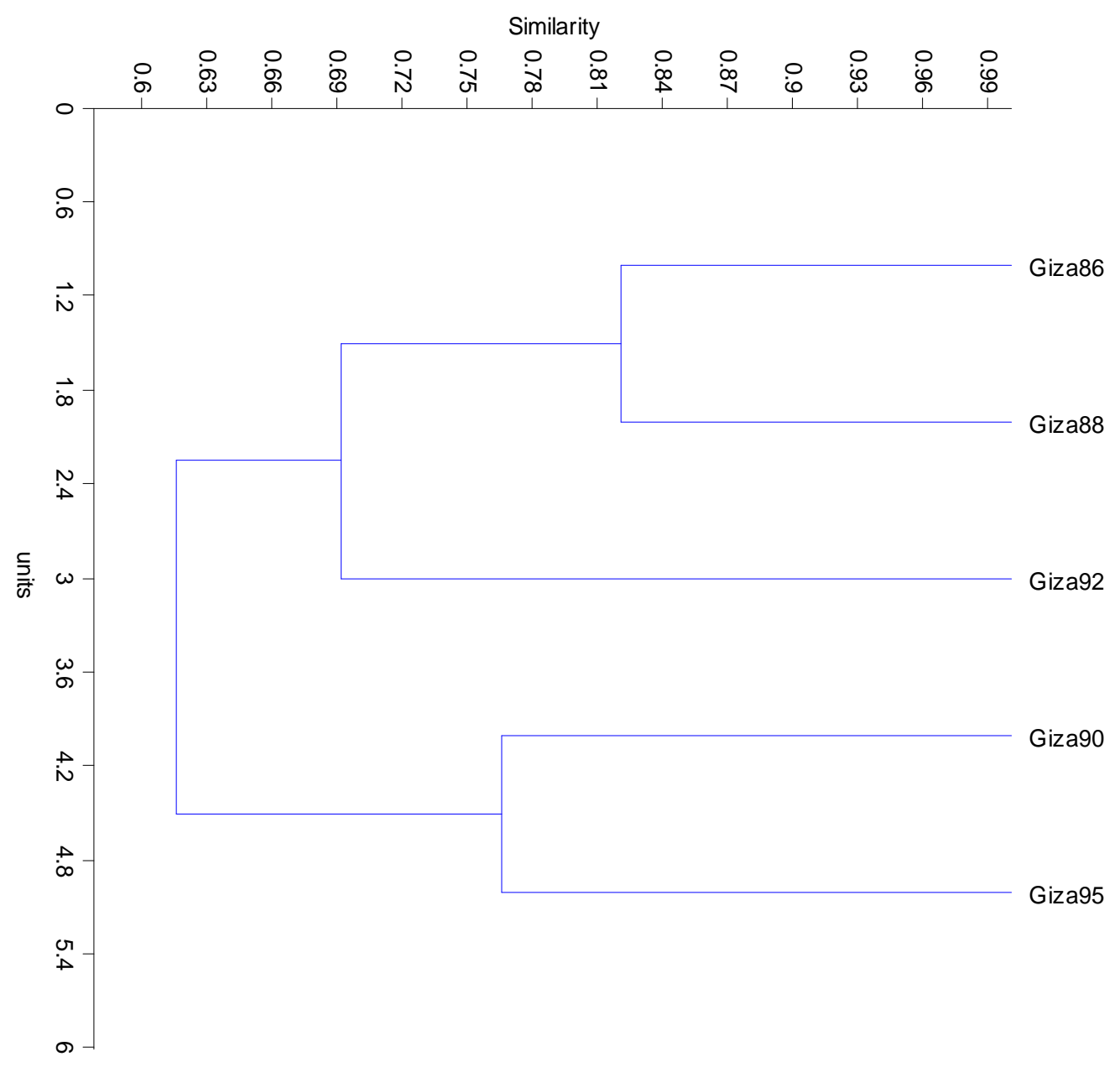

Figure 3. Genetic diversity of cotton varieties based on morphological, biochemical and technological markers 


\section{REFERENCES}

Abd El-Glil, H.E. 2001. Studies on the Egyptian cotton grade by the high-volume instrument (H.V.I). M.S. thesis, Fac. Agric., Saba-Basha, Alex. Univ., Egypt.

Abdel-Tawab, F. M., E. M. Fahmy, M. A. Rashed, A. ElSoudy and M. O. Ismael. 1990. Use of seed protein PAGE, esterase isozyme patterns and immunodiffusion analysis to differentiate between cotton cultivars of two different species. Egypt. J. Genet. Cytol., 19: 37-46.

Abdurakhmonov, I.Y. 2007. Exploiting Genetic Diversity, Proceedings of World Cotton Research Conference-4, P2153, Lubbock, Texas, USA, September 10-14, 2007

Anderson, C. G. 1999. Cotton marketing. In: Smith, C.W, Cothren, J.T.(eds) Cotton: Origin, History, Technology and Production. Wiley, New York, pp: 659-679 C.F. Frelichowski et. al., 2006.

Bardak A. and Y. B?lek 2012. Genetic diversity of diploid and tetraploid cottons determined by SSR and ISSR markers. Turk J Field Crops 17: 139-144.

Bardakci, F. and D. O. F. Skibinski. 1999. A polymorphic SCAR-RAPD marker between.species of tilapia. Animal Genet. 30: 78-79.

Batisha, I.Z. 2005. Seed cotton levels and lint grades analyses of some Egyptian cotton cultivars. Ph.D. thesis, Fac. Agric., Saba Basha, Alex. Univ., Egypt.

Bowles Welsh, D.J .1990. Defense-related proteins in higher plants, Ann. Rev. 59: 873-907.

Campbell, B.T., S. Saha, R. Percy, J.Frelichowski, J.N.Jenkins, W.Park, C.D.Mayee, V.Gotmare, D.Dessauw, M.Gband, X. Du, Y. Jia, G. Constaple, S. Dillon, I.Y.Abdurakhmonov, A. Abdukarimov, S.M. Rizaeva, A.A.Abdullaev, P.A.V. Barrose, J.G.Padua, L.V. Hoffman and L.Podolnaya 2010. Status of Global Cotton Germplasm Resources. Crop Science, Vol. 50, No. 4.July 2010. pp:1161-1179, ISSN 1435-0653

Dawwam, H.A., F.A. Hendawy, R.M Esmail and H. ElShymaa Mahros.2009. Inheritance of some quantitative characters of Egyptian cotton (Gossypium barbadense L). 6 International Plant Breeding Conference, Ismailia, Egypt.May. pp: 3-5

De Almeida, V.C., L.V.Hoffman, G.K.I.Yokomizo, J.N.da Costa, M.Giband, P.A.V. Barroso.2009. In situ Genetic Characterization of Gossypium barbadense Populations from the States of Para and Amapa, Brazil. Pesquisa Agropecuaria Brasileira, Vol. 44. No. 7.July 2009. pp:719-725.ISSN 0100-204X.

Doebley, J. 1989.Isozymic evidence and evolution of crop plants. In: D.E. Soltis, P.S. Soltis [eds.], Isozymes in plant biology. Dioscorides Press, Portland, Oregon: 165-189.

El-Defrawy, M. M., M.Mervat Hashad and E. N. Elsayed. 2004. Molecular polymorphism in egyptian cotton (Gossypium barbadense L.). Assiut J. Agric. Sci. 35: 8396.

Erkılınç A, M. Karaca .2005. Assessment of genetic variation in some cotton varieties (Gossypium hirsutum L.) grown in Turkey using microsatellite. Akdeniz Univ Ziraat Fak Derg 18: 201-206.

Farooq, S., N. Iqbal and A. A. Zaidi.1999. Isozyme markers in cotton breeding 1. Standardization of different isozyme systems for identification of different cultivars of cotton (Gossypium hirsutum). Pak. J. Bot.31: 5-20

Foulk, J.A., G.R. Gamble, C. Price, H. Senter and W.R. Meredith Jr.2008. Relationship of fiber properties to vortex yarn quality via partial least squares. National Cotton Council Beltwide Cotton Conference, January 811. 2008. Nashville, Tennessee, USA, pp: 1472-1485.

Gaspar, T., C. Penel, T. Thorpe, and H. Greppin. 1982. Peroxidases: A survey of their biochemiappropriate peroxidase substrates availcal and physiological roles in higher plants.Univ. of Geneva, Switzerland.

Hussein, Ebtissam H. A, M. Sh.Al-Said, H. A. El-Itriby, and M. A. Madkour .2002. Genotyping Egyptian Cotton Varieties (G. barbadense) using molecular markers. (Poster) Biotechnology and Sustainable Development Voices of the South and North Conf. Held at the Bibliotheca Alexandrina Conference Center, March 16-20. Alexandria, Egypt.

Ibrahim, A.E.I. 2010. Effect of Cotton Cultivar and Seed Grid Adjustment on Ginning Efficiency and Fiber Properties. J. Appl. Sci. Res.6(11): 1589-1595

Ibrahim, A.E.I. 2013. Effect of cotton variety and lint grade on some fiber and yarn properties. J. Appl. Sci. Res.9(6): 4015-4020

Jing, K. Z., S. Ji-Zhong, Z. Jin-Fa, N. YiChun and L. Jin-Lan .2000. Genetic diversity evaluation of some Chinese elite cotton varieties with RAPD markers. Acta Genetica Sinica, 27: 817-823.

Kalir, A. G.Omri and A. Poljakoff-Mayber. 1984. Peroxidase and catalase activity in leaves of Halimione portulacoides exposed to salinity.Phys. Plant. 62: 238-244.

Masoud, S., H.Zahra, Shahriari, H. Rokneizadeh and Zahra Noormohammadi .2007. RAPD and cytogenetic study of some tetraploid Cotton (Gossypium hirsutum L.) cultivars and their hybrids. Cytologia, 72: 77-82.

Mather, K. and J.L. Jinks.1982. Biometrical Genetics 3 Ed. Chapman and Hall, London, pp: 396

Mauer, F. M.1954. Origin and Taxonomy of Cotton, In: Cotton, 383, Academy of Sciences of USSR, Tashkent, Uzbekistan (In Russian)

Melchinger, A. E., M. M. Messmer, M. Lee, W. L. Woodman and K. R. Lamkey .1991. Diversity and relationships among US maize inbreds revealed by restriction fragment length polymorphisms. Crop Sci., 31: 669-678.

Mohamed, Z. R., N.R. Abdelsalam, K. F. Abdel Latif and R. M. Abdelhady.2017. Genetic Diversity of Fig (Ficus carica L.) Based on Morphological Characters and TwoWay Hierarchical Cluster Analysis. Alex. Sci. Exch. J. 38:168-174 
Muhammad, A., M. Ur. Rahman, J. I. Mirza and Y. Zafar .2009.Parentage confirmation of cotton hybrids using molecular markers. Pak. J. Bot., 41: 695-701.

Murray, M.G. and W.F. Thompson.1980.Rapid isolation of high molecular weight plant DNA. Nucleic Acids Res. 8: 4321-4325.

Percival, A.E., J.M. Stewart and J.F. Wendel.1999. Taxonomy and Germplasm Resources, In: Cotton: Origin, History, Technology and Production, C.W. Smith and J.T. Cothren, (Ed), 33-63, ISBN 978-0-471-18045-6 John Wiley, New York.

Persson, K. Falt, A.S. Von. and R.Bothmer. 2001. Genetic diversity of allozymes in turnip(Brassica rapa L.var. rapa) from the Nordic area.Hereditas.134: 43-52.

Pillay, M. and G.O. Myers.1999. Genetic Diversity in Cotton Assessed by Variation in Ribosomal RNA Genes and AFLP Markers. Crop Sci.Vol. 39.No. 6. November 1999.pp. 1881-1886, ISSN 1435-0653

Rahman, M., D. Hussain and Y. Zafar .2002. Estimation of divergence among elite cotton cultivars genotypes by DNA fingerprinting technology. Crop Sci., 42: 21372144.

Rana, M.K., V.P.Singh and K.V. Bhat.2005. Assessment of Genetic Diversity in Upland Cotton (Gossypium hirsutum L.) Breeding Lines by Using Amplified Fragment Length Polymorphism (AFLP) Markers and Morphological Characteristics. Gen. Res. Crop Evo.Vol. 52. No. 8. December 2005. pp: 989-997.ISSN 15735109

Richard, G.P., G.C. Roy and Z. Jinfa .2006. Genetic variation for agronomic and fiber properties in an introgressed recombinant inbred population of cotton. Crop Sci..46:1311-1317.
Rohlf, F.J. 2000.On the use of shape spaces to compare morphometric method. Hystrix, Italian J. Mammology (n.s.).11(1): 8-24.

Saif, I. , M.A. Seehy S. Riad and M. Elbagoury. 2017. Molecular Characterization of Some Egyptian cotton Varieties Alex. Sci. Exch. J. 38:44-52.

Scandalios, J.G.1994.Regulation and properties of plant catalases. In: Foyer CH, Mullineaux PM, editors. Causes of Photooxidative Stress and Amelioration of Defense Systems in Plants. Boca Raton, FL.CRC Press.pp:275315.

Surgun Y., B.C?1, B. Bürün.2012. Genetic diversity and identification of some Turkish cotton genotypes (Gossypium hirsutum L.) by RAPD-PCR analysis. Turk J. Biol. 36: 143-150.

Ulloa, M., J.M.Stewart, E.A.Garcia-C, A. S. Goday, A.Gaytan-M and N.S. Acosta. 2006.Cotton Genetic Resources in the Western States of Mexico: in situ Conservation Status and Germplasm Collection for ex situ Preservation. Gen.Res. Crop Evo. Vol. 53:653-668, ISSN 1573-5109

Williams, J. G. K., A. R. Kublik, K. J. Livak, J. A. Rafaliski and S. V. Tingey (1990). DNA polymorphisms amplified by arbitrary primers are useful as genetic markers. Nucleic Acids Res., 18: 65316535.

Yeates, S. J., G.A. Constaple and T. McCumstie .2010. Irrigated cotton in the tropical dry season. III: Impact of temperature, cultivar and sowing date on fiber quality. Field Crops Res.116:300-307.

Zahid M., F. A. S. Raheel, S. Dasti, Shahzadi, M. Athar and M. Qayyum .2009. Genetic diversity analysis of the species of Gossypium by using RAPD markers. Afri.J.of Biotechn. 8: 36913697. 


\section{الملخص العربي}

\section{تقييم التنوع الوراثي لبعض اصناف القطن المصرى اعتمادا على المعلمات الجزيئية والتكنولوجية}

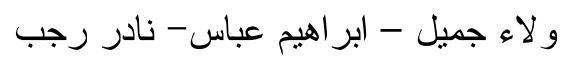

للتحكيم وإختبار ات القطن بالأسكندرية لتقدير الصفات التكنولوجية لألياف أصناف القطن تحت الدراسة وهئ طول الالياف، إنتظامية طول الالياف، نسبة الألياف وفى لهال القصيرة، متانة وإسنطالة الالياف، نضج الالياف، قراءة الميكرونير، درجة إنعكاس اللون ودرجة الإصفرار. اوضحت النتائج ان هناك درجات تشابة وصلت الى . . 1

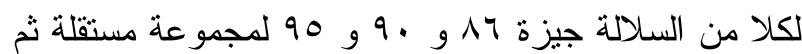
كانت السلالات جيزة 11 و ب ra معا فى مجموعة اخرى بنفس درجة النتابة ... 1\% وكانت المجموعتين متشابهتان

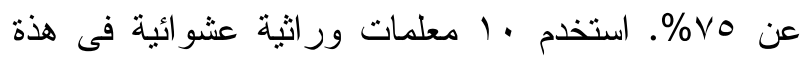

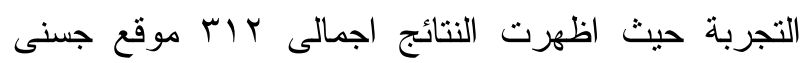

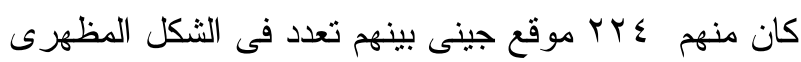

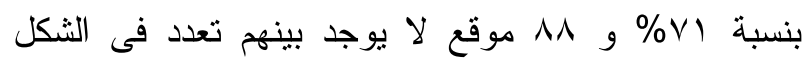

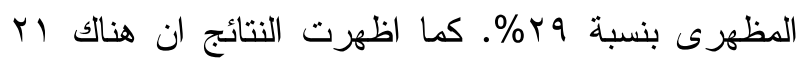
موقع جينى متخصص لكل السلالات موضع الدراسة. من خلال هذة النتائج المتحصل عليها أمكن قياس مدى التعدد والتتوع الوراثى بين أصناف القطن المصرى باستخدام القياسات المورفولوجية و التكنولوجية و البيوكيمائية و الجزيئية التى قد تعتبر دليل يؤخذ في الإعتبار فى برامج تربية أصناف القطن المصري الجديدة في المستقبل.
يعتبر محصول القطن من المحاصيل الاقتصادية الهامة على مسنوى العالم، حيث يدخل فى العديد من صناعة المنسوجات. وتتميز جمهورية مصر العربية بانواع اصيلة من القطن المصرى طويل وقصير التيلة ذا الجودة العالية دون غيرها من البلدان على مستوى العالم. اجريت هذة

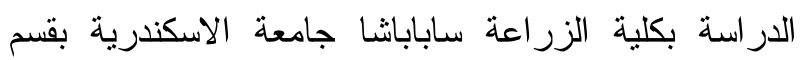

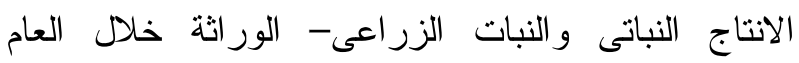

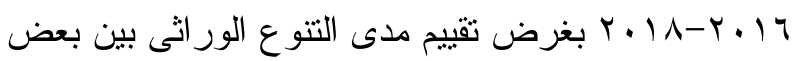

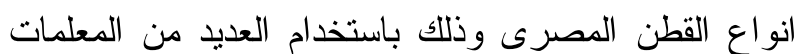
مثل المعلمات المورفولوجية و البيوكيمائية و التكنولوجية و الجزيئية. استخدم خلال هذة الدراسة خمسة اصناف من القطن الدصرى هى جيزة بول، جيزة 11 (أصناف فائقة

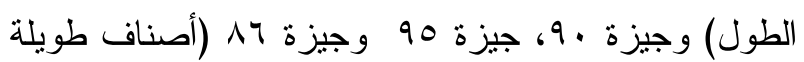
التيلة)، ونم الحصول على القطن الزهر (القطن قبل حلجة) لهذه الأصناف من معهد بحوث القطن مركز اللبحوث الزر اعية من خلال محطاتة بالوجة البحرى و القبلى. تم حلج من التحن (فصل الشعرة عن البذرة) هذة الأصناف في محلج قسم الإنتاج النباتى كلية الزراعة سابا باثا حيث إستخدمت البذور الناتجة بعد الحلج في زر اعة الأصناف بالتجربة، وتم إرسال عينات من القطن الثعر إلى معمل الهيئة العامة 